\title{
UNIQUE PRESENTATION OF AN 8p DELETION IN A DISCORDANT TWIN WITH ATRIOVENTRICULAR CANAL DEFECT AND PROLONGED HYPOGLYCEMIA
}

\author{
Kumar P*, Elshershari H, Parashette KR, Ize-Ludlow D, Harris C
}

\begin{abstract}
*Corresponding Author: Praveen Kumar, Department of Pediatrics, University of Illinois at Chicago, 840 S. Wood Street, Chicago, IL 60612, USA; Tel.: +312-850-0375; Fax: +312-4130243; E-mail: praveenk@uic.edu
\end{abstract}

\begin{abstract}
We report on a del(8)(p22) in a severe intrauterine growth retarded newborn with balanced atrioventricular canal defect and prolonged hyperinsulinemic hypoglycemia of infancy. Atrioventricular septal defects are associated with terminal deletions of chromosome $8 \mathrm{p}$. Hyperinsulinism during infancy represents a group of clinically, genetically and morphologically heterogeneous disorders and is also associated with mutations in several genes. However, such $8 \mathrm{p}$ deletions are not associated with hyperinsulinemic hypoglycemia of infancy.

Key words: Del(8)(p22); Atrioventricular canal defect; Congenital hyperinsulinism; Hypoglycemia
\end{abstract}

\section{INTRODUCTION}

The congenital heart disorders associated with chromosome abnormalities are approximately $12 \%$. Atrioventricular canal defects have extensive genetic heterogeneity [1], occurring frequently in trisomy 21 and are strongly associated with $8 \mathrm{p}$ syndrome [2]. A zinc-finger transcription factor GATA4 encoded at 8 p22-23 is implicated as a cause of cardiac septal

Department of Pediatrics, University of Illinois at Chicago, Chicago, IL, USA defects [3]. Our patient had prolonged hyperinsulinemic hypoglycemia but this region of $8 p$ is not associated with hypoglycemia.

\section{CASE REPORT}

Discordant, dichorionic diamniotic twins were born to a 21-year-old African-American gravida 3 para 1 mother via emergency C-section at 36 weeks gestation. The pregnancy was complicated by tobacco use. The mother had a healthy 3-year-old female and one spontaneous abortion in the first trimester. The birth-weight of female twin A was 860 $\mathrm{g}(<3 \%)$, length $30.5 \mathrm{~cm}(<3 \%)$ and head circumference $25 \mathrm{~cm}(<3 \%)$. The birth-weight of female twin B was 2060 gm (3-10\%), length $40.5 \mathrm{~cm}(<10 \%)$ and head circumference $30.5 \mathrm{~cm}(3-10 \%)$.

The physical examination of twin A at birth revealed a triangular face, low set and posterior rotated ears, micrognathia and high arched palate. The APGAR scores at birth were 1 and 7 at 1 and 5 min., respectively. On cardiovascular examination, grade $2 / 6$ systolic ejection murmur at the left sternal border was heard. Echocardiography showed a complete balanced atrioventricular canal defect, pulmonary stenosis (peak gradient of $63.2 \mathrm{mmHg}$ ), a small muscular ventricular septal defect and a secundum atrial septal defect (Figure 1). Repeated echocar- 


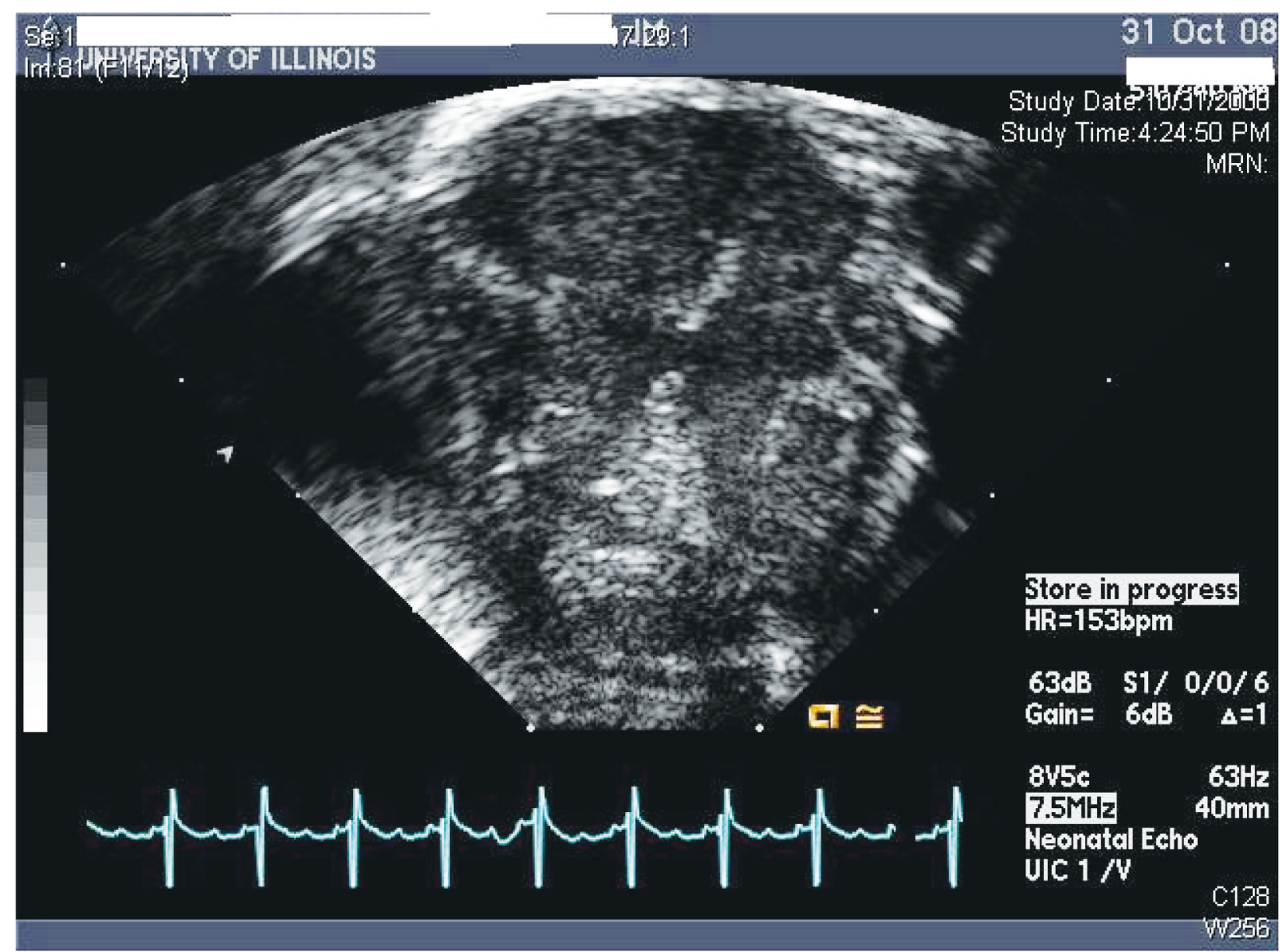

Figure 1. Two-dimensional echocardiography 4 chamber view showing balanced atrioventricular canal defect.

diography showed progressive valvular pulmonary stenosis (peak gradient of $104.9 \mathrm{~mm} \mathrm{Hg}$ ).Twin A remained hospitalized for 4 months and during this time developed poor oral feeding, pelviectasis on the left side, hypertension which required hydralazine and methyldopa, bilateral inguinal hernia, distal renal tubular acidosis, Type 4B.

Twin A developed nonketotic hypoglycemia at 2 months of age. The blood glucose ranged between 26.0 and $40.0 \mathrm{mg} / \mathrm{dL}$ and was associated with in- appropriate insulin levels (Table 1). During a glucagon stimulation test $(0.5 \mathrm{mg}$ intramuscular $)$ the patient's glucose increased from 48.0 to $82.0 \mathrm{mg} /$ $\mathrm{dL}$. The hypoglycemia resolved with diazoxide (5 $\mathrm{mg} / \mathrm{kg}$ / day) which was discontinued at 11 months of age without recurrence of hypoglycemia. Cytogenetic testing at the Chicago Laboratory, University of Illinois Medical Center, Chicago, IL, USA, revealed a small deletion of the terminal bands of the short arm of chromosome 8.46,XX, del (8)

Table 1. Results of critical samples during episodes of hypoglycemia

\begin{tabular}{|c|c|c|c|c|}
\hline $\begin{array}{c}\text { Day of } \\
\text { Life }\end{array}$ & $\begin{array}{c}\text { Serum Glucose } \\
(\mathrm{mg} / \mathrm{dL})\end{array}$ & $\begin{array}{c}\text { Serum Insulin } \\
(\mu \mathrm{IU} / \mathrm{mL})\end{array}$ & $\begin{array}{c}\text { Serum Acetone } \\
(<10 \mathrm{mg} \text { aceto-acetic } \\
\text { acid per dL })\end{array}$ & $\begin{array}{c}\text { Serum Free Fatty Acids } \\
(\mathrm{mmol} / \mathrm{L})\end{array}$ \\
\hline 67 & 39.0 & 6.0 & Negative & 0.40 \\
\hline 70 & 49.0 & 4.0 & Negative & 0.43 \\
\hline 76 & 48.0 & 2.0 & Negative & n.a. \\
\hline 88 & 46.0 & 2.0 & Negative & 0.24 \\
\hline
\end{tabular}

n.a.: not available 
(p22).ish del(8)(p23.3 p23.3)(D8S504-). Microarray analysis at the Signature Genomics Laboratory, Washington, DC, USA, confirmed single copy loss of 673 oligonucleotide probes at the subtelomeric region of the short arm of chromosome 8 . The patient had global developmental delay. Twin B was normal on physical examination and echocardiography and had no hypoglycemia. The limited family history is negative for diabetes mellitus.

The patient's cardiovascular anomalies were attended to at 6 months of age with repair of the atrioventricular canal defect and pulmonic stenosis. The postoperative period was complicated by supraventricular tachycardia, junctional ectopic tachycardia, atrial fibrillation, functional AV blocks and multifocal atrial ectopic rhythm. The arrhythmias were well controlled with amiodarone and digoxin.

\section{DISCUSSION}

The first patient with an $8 \mathrm{p}$ deletion and congenital heart disease was reported in 1973 [4]. Such children frequently show congenital heart defects and a variable degree of mental retardation. In contrast, facial anomalies are subtle [5]. Congenital heart diseases which are phenotypically linked to chromosome 8 p22-23 have a locus between D8S264 and D8S1827 [3], which is associated with GATA4, a zinc-finger transcription factor. Our patient's deleted locus was (D8S504). In mouse embryos, this transcription factor is necessary for normal folding that later on gives rise to heart tube and pericardial cavity [6]. Therefore, GATA4 is required for development of all four chambers. GATA4 also interacts with TBX5 for normal development of cardiac septum [3]. Thus, an $8 p$ deletion causes haploinsufficiency of GATA4 which is responsible for congenital heart diseases.

Hyperinsulinism during infancy causes transient or permanent hypoglycemia. Prematurity, intrauterine growth restriction and congestive heart failure may result in transient neonatal hypoglycemia without hyperinsulinemia. Perinatal asphyxia can result in hyperinsulinemic hypoglycemia, but it presents during the first days of life. There are several genetic causes of hyperinsulinemic hypoglycemia including mutations in the genes encoding the SUR1/Kir6.2 complex [7], glutamate dehydrogenase, glucokinase and 3-hydroxyacyl-CoA dehydrogenase, but in many cases the genetic etiology is unknown [8]. Laboratory diagnosis of hyperinsulinemic hypoglycemia of infancy is based on persistent hypoglycemia, inappropriately elevated plasma insulin concentration during hypoglycemia, low ketones and increased glycemic response to glucagon. Hoe et al. [9] reported 26 cases of prolonged neonatal hyperinsulinism where genetic etiology underlying glucose regulation was unknown and 95\% neonates demonstrated good response to diazoxide. Our patient had late onset prolonged hypoglycemia with good response to diazoxide. The laboratory results confirmed non ketotic hypoglycemia with glycemic response to glucagon, inappropriate insulin levels during hypoglycemic episodes and low serum free fatty acid concentration. The response to glucagon and hyperinsulinism ruled out glycogen storage defects. In our patient, chromosome 8 locus D8S504- onwards is deleted. There are no known genes that regulate insulin secretion or action within this interval. One study has reported linkage of susceptibility to type 2 diabetes on indigenous Australians to the nearby marker D8S549 [10]. It is possible that a mutation vs. deletion in such a gene could cause opposite phenotypes, hyperinsulinemia $v s$. increased risk for Type 2 diabetes.

\section{REFERENCES}

1. Maslen CL. Molecular genetics of atrioventricular septal defects. Curr Opin Cardiol 2004; 19(3): 205-210.

2. Marino B, Reale A, Giannotti A, Digilio MC, Dallapiccola B. Nonrandom association of atrioventricular canal and del (8p) syndrome. Am J Med Genet 1992; 42(4): 424-427.

3. Garg V, Kathiriya IS, Barnes R, Schluterman MK, King IN, Butler CA, Rothrock CR, Eapen RS, Hirayama- Yamada K, Joo K, Matsuoka R, Cohen JC, Srivastava D. GATA4 mutations cause human congenital heart defects and reveal an interaction with TBX5. Nature 2003; 424(6947): 443-447.

4. Lubs ML, Lubs HA. Chromosome identification-techniques and applications in biology and medicine. Nobel Symposia 1973; 8: 241-250. 
5. Hutchinson R, Wilson M, Voullaire L. Distal $8 \mathrm{p}$ deletion $(8 \mathrm{p} 23.1 \rightarrow 8 \mathrm{pter})$ : a common deletion? J Med Genet 1992; 29(6): 407-411.

6. Kuo CT, Morrisey EE, Anandappa R, Sigrist K, Lu MM, Parmacek MS, Soudais, C, Leiden JM. GATA4 transcription factor is required for ventral morphogenesis and heart tube formation. Genes Dev 1997; 11(8): 1048-1060.

7. Dunne MJ, Kane C, Shepherd RM, Sanchez JA, James RF, Johnson PR, Aynsley-Green A, Lu S, Clement JP, Lindley KJ, Seino S, Aguilar-Bryan L, Gonzalez G, Milla PJ. Familial persistent hyperinsulinemic hypoglycemia of infancy and mutations in the sulfonylurea receptor. $\mathrm{N}$ Eng $\mathrm{J}$ Med 1997; 336(10): 703-706.
8. Dekelbab BH, Sperling MA. Recent advances in hyperinsulinemic hypoglycemia of infancy. Acta Pediatrica 2006; 95(10): 11571164.

9. Hoe FM, Thornton PS, Wanner LA, Steinkrauss L, Simmons RA, Stanley CA.. Clinical features and insulin regulation in infants with a syndrome of prolonged neonatal hyperinsulinism. J Pediatr 2006; 148(2): 207-212.

10. Busfield F, Duffy DL, Kesting JB, Walker SM, Lovelock PK, Good D, Tate H, Watego D, Marczak M, Hayman N, Shaw JT. A genomewide search for type 2 diabetes-susceptibility genes in indigenous Australians. Am J Hum Genet 2002; 70(2): 349-357. 